\title{
Reading to Write: A Strategy for Improving the Writing Performance of Students of English Language: A Case Study of Ogba/Egbema/Ndoni Local Government Area of Rivers State
}

\author{
Anthony Ugboja ${ }^{1}$, Rosemary Eze Ifunanya ${ }^{2} \&$ Moses $_{\text {Offor }}{ }^{3}$ \\ ${ }^{1}$ Department of Curriculum Studies and Educational Technology, University of Port Harcourt, Rivers State, Nigeria \\ ${ }^{2}$ Department of General studies, Eha- Amufu College of Education Enugu State, Nigeria \\ ${ }^{3}$ Department of Science Education, University of Nigeria Nsukka, Enugu State Nigeria \\ Correspondence: Anthony Ugboja, Department of Curriculum Studies and Educational Technology, University of \\ Port Harcourt, Rivers State, Nigeria
}

Received: January 18, 2018

Accepted: February 6, $2018 \quad$ Online Published: February 23, 2018

doi:10.5430/elr.v7n1p44

URL: https://doi.org/10.5430/elr.v7n1p44

\begin{abstract}
This study focuses on Reading to Write as a strategy for improving the writing performance of students of English language in Ogba/Egbema/Ndoni Local Government Area of Rivers State. An intact class was used to investigate reading to write as a way of improving the writing performance of secondary school students. The research focused on a single class, that is, the entire population of the students in SS 2, which is made up of 56 students. This research work has adopted the transactional theory of writing and reading as the theoretical framework. Two types of questionnaires were used because of pre-test and post-test, study four essay topics were used to test the students initial competent in writing skills before we started the training through reading to improve writing. Simple percentage was used for the pre-test and post-test study. Mean and Standard Deviation was used to analyze the student's achievement test for both pretest and posttest while ANCOVA was used to test the hypothesis at 0.5 level of significant.

From the result from pre-test and post-test, it is crystal clear that reading to write as a strategy can help to improve writing performance of the students and majority of the students has confirmed that this method should be apply in their class room in other to improve their writing skills. Recommendations are also provided.Key
\end{abstract}

Keywords: reading to write, strategy

\section{Introduction}

In this modern age, inability to read and write is a great deprivation .There is this saying that 'knowledge is power' but in this modern world, ability to read and write is one of the ways of social interactions and it enriches one's personal life. This paper explains the positive relationship that exists between reading and writing, the focus is on the reading to write as a strategy to improve writing performance of students of English language. Many scholars acknowledge the fact that continuous reading is the only key to success in school. Communicative competence demand appropriate syntactically mature writing skills, and the best way to improve this skills in students is by developing reading skills which will lead to competence in writing skills. One of the major problems of this study is that secondary school students rarely engage in recreational reading. They read only in preparation for an examination or test. This fact was confirmed during pre-study survey of the target students.

Experience and research have also shown that composition writing amongst secondary school students is very poor. Therefore, this writing disability amongst our students is linked to the poor reading habits of the students. It is very pertinent to say here that since reading and writing are drawn from the same pool of background knowledge, this research deems it necessary to investigate the impact of reading as a basis for the writing performance of students. The objective of the study is to find out the type of reading that the students of secondary school engage in most and to also critically examine how often they engage in reading to write exercise and when they like to read most.

The following research questions were put forward to guide the study

- What type of reading do you engage in most?

- How often do you engage reading to write exercise? 
- When do you like to read most?

To analyze the achievements of students in composition writing for both pre-test and post-test, the following research question are put forward:

- What are the Mean achievement sore of students taught using reading to write method of learning English composition and those taught using conventional method?

- What are the mean achievement scores of male female students in reading to write as a strategy to improving writing performance of students in secondary schools?

This hypothesis was tested:

H01: There is no significance difference in the mean achievement scores of students taught using reading to write method of learning compositing and those taught using conventional method of writing.

This study will be relevant to both teachers and students especially teachers of English language to develop the best method of teaching writing in secondary schools. It will help all the stakeholders in education to lay more emphasis on reading and writing as the basic foundation for any educational achievement. It is the intention of this researcher that the outcome of this research would stir up the government to provide and equip schools with reading material. The study would be useful to other researchers who would want to delve into the field in the future to have an insight into the important of reading as it relates to performance in writing amongst secondary schools students.

This study covers all senior secondary school students of English language in Ogba /Egbema/Ndoni Local Goernment Area of Rivers state.

\section{Review of Literature}

Research has proved that students who are exposed to additional reading experience perform better in writing than those who concentrate only on writing practices or study formal grammar. The research has shown that the poor reading culture can be linked to the poor writing ability of students of English language. Heys (1974) is of the opinion that better readers tend to produce more grammatically correct writings than poor readers. The reason is obvious, by reading great books, the reader adopt the style, the structure, including the figures of speech of the writer. The reader consciously or on consciously absorbs the style in his writing to become a better writer.

Olagide (1997), opines that University students can improve in their comprehension reading not only by cultivating reading habit but also to read extensively and intensively across all disciplines. The present study also believes that reading across discipline will improve the writing skills of our student. Olagide investigated the comprehension reading among the university students and concluded that reading across all discipline will help to increase their performance in comprehension reading. The present study investigate reading to write among senior (ss two) secondary schools as a strategy to improve their writing performance.

Yani (2003) reveals that reading habits of Nigerians education is a serious issue since it concerns national development, he further emphasizes that in a developing country like Nigeria, and reading habits should not be overlooked. Nweke (1990) in the same view states that reading has effective role to play in the development of an individual. Sangaeo (1999) also posits that a reading habit must be promoted from an early stage. This view is highly supported by Yusuf (2007) who concludes by saying that children imbibe good character during their formative years. The above review show that, apart from the fact that good reading habits amongst students prepare them to be good writers, it also prepares students to have good moral character, it helps in the development of an individual, above all it help in national development especially in a developing country like Nigeria.

\section{Theoretical Framework}

This research work has adopted the Transactional Theory of Writing and Reading as the theoretical framework using the version of Louise (1988). The theory stresses on the relationship between reading and writing. There is already a wild spread view from other researcher that these two linguistic activities are drawn from the same background. Therefore the transactional theory of Louise seeks to examine this assumption with care to see how they are actually related. This is to say that this theory is built on the general trend, to present a coherent theoretical approach to the interrelationship that exists between reading and writing processes.

The relationship between reading and writing embraces the network of parallelism and differences. Both of them share necessary associations with texts. Despite the similarities, there is also a significant difference between these two basic language skills; the writer start with a blank page he must produce text or information out of it whereas the reader starts 
with the already written text and must produce meaning out of it. That is, reading is an integral part of the writing process.

The transactional nature of language and concepts of transaction and selective attention illuminates what happens in reading. A very reading act is an event, a transaction involving a particular reader and particular contexts. Certain organismic states, certain ranges of feelings, certain verbal or symbolic linkages are stirred up in the linguistic reservoir. The transactional theory believes that the meaning does not reside on ready-made in the text or in the reader, but happens during the transaction between the reader and text.

This present research is of the same view that, the readers retain the information from the text, during transaction and adopt the structure, and emulate the style and culture of the writer and consequently transfer it to his on writing.

The same way readers approach the text, writers are also facing black page. Writers dwell on the past experiences of language written and spoken in life situation, provides the materials from which the text will be constructed. In relating it to the reader, any new information grow out of, are restructuring or additional stock of experience from the writer. That is to say that; writers seek information from the text to improve their writing through reading.

\section{Methodology}

This study is a case study. The study does not focus on any sample since it is adopting an intact class. The action research is focused on a single class, that is, the entire population of the student in SS 2, which is made up of 56 students. This class is chosen because SS1 are just beginner in SS classes and need a lots of orientation coupled with some students that have been admitted late to the class, it is not ideal to use them for the research. And SS3 are very busy preparing for the West African Senior School Certificate Examination. Therefore, using them for this type of research is a distraction. These are the reasons while we chose SS2 class. Meanwhile, the reading exercis we engaged in this research has actually prepared the SS2 for their WASSCE examination.

Questionnaires were used as the instrument for the study. Two set of questionnaires were structured because of the pre-test and post-test to check the interest in reading skills and their pattern of reading. Various research instruments that were employed for this research includes: observation, questionnaire, class discussion, and writing exercise.

A questionnaire was administered to the students before we commence the reading exercise. After which the list of books selected by the students was administered. Students were allowed to select the books by themselves in other not to avoid imposing books on the students. Students are allowed to select the ones they want to read in a particular week. This is done in other to motivate them.

An oral discussion is organized every week on every read title. The discussion covered the following information; the story line, the characters, the language, the events, introduction, body and conclusion.

Four essay topics were used to test the students initial competent in writing skills before we start the training through reading to improve writing. During the process of training, eight reading materials were used; five novels and three comprehension from their comprehensive English. Sixteen novels were given to the students to select eight and twelve comprehension to select three. This revision focuses on the major aspect of writing.

At the end of the reading exercise, the results obtained were analyzed using simple percentage, mean and standard deviation and ANCOLVA was used to test hypothesis. 
Table 1. Pre-study of the students reading

Number of students: 56

\begin{tabular}{|c|c|c|c|c|}
\hline \multirow[t]{2}{*}{ No } & \multirow{2}{*}{\multicolumn{2}{|c|}{ Item }} & \multicolumn{2}{|l|}{ Response } \\
\hline & & & No of respondents & Percentage (100\%) \\
\hline \multirow[t]{6}{*}{1} & \multicolumn{4}{|c|}{ What type of reading do you like most? } \\
\hline & & Reading for pleasure & 16 & $29 \%$ \\
\hline & & Reading for examination & 26 & $46 \%$ \\
\hline & & News paper reading & 6 & $10 \%$ \\
\hline & & Text book reading & 8 & $14 \%$ \\
\hline & Tot & al no of respondents & 56 & $100 \%$ \\
\hline \multirow[t]{8}{*}{2} & \multicolumn{4}{|c|}{$\begin{array}{l}\text { How often do you engage in reading to write } \\
\text { exercise? }\end{array}$} \\
\hline & • & Once or twice a week & 10 & $18 \%$ \\
\hline & • & Every day & 0 & $0 \%$ \\
\hline & • & During composition exercise & 12 & $21 \%$ \\
\hline & • & Once a term & 16 & $29 \%$ \\
\hline & • & Twice in a term & 8 & $14 \%$ \\
\hline & • & None of the above & 10 & $18 \%$ \\
\hline & Tot & al No of respondents & 56 & $100 \%$ \\
\hline \multirow[t]{5}{*}{3} & \multicolumn{4}{|c|}{ When do you like to read most? } \\
\hline & • & During examination & 26 & $46 \%$ \\
\hline & • & During assignment & 20 & $36 \%$ \\
\hline & & During leisure & 10 & $18 \%$ \\
\hline & Total No of & respondents & 56 & $100 \%$ \\
\hline
\end{tabular}

Table 2. Reading/ writing assessment (post-study)

Number of Respondents: 56

\begin{tabular}{|c|c|c|c|c|c|c|c|}
\hline No & Items & Yes & $\%$ & No & $\%$ & Not sure & $\%$ \\
\hline 1 & $\begin{array}{l}\text { Did you enjoy the reading we just } \\
\text { concluded? }\end{array}$ & 50 & $89 \%$ & 2 & $4 \%$ & 4 & $7 \%$ \\
\hline 2 & $\begin{array}{l}\text { Were you able to complete all the selected } \\
\text { books? }\end{array}$ & 36 & $64 \%$ & 3 & $5 \%$ & 7 & $12 \%$ \\
\hline 3 & Will this exercise help your writing skills? & 40 & $71 \%$ & 2 & $4 \%$ & 14 & $25 \%$ \\
\hline 4 & $\begin{array}{l}\text { Will you like your teachers to adopt this } \\
\text { method in your class? }\end{array}$ & 46 & $82 \%$ & 0 & $0 \%$ & 10 & $18 \%$ \\
\hline 5 & $\begin{array}{l}\text { Will this exercise make you to read after } \\
\text { this session? }\end{array}$ & 51 & $91 \%$ & 0 & $0 \%$ & 5 & $9 \%$ \\
\hline 6 & $\begin{array}{l}\text { Did this exercise help you to improve on } \\
\text { your language skills? }\end{array}$ & 41 & $73 \%$ & 3 & $5 \%$ & 12 & $21 \%$ \\
\hline 7 & Was it difficult for you to buy those books? & 19 & $34 \%$ & 27 & $48 \%$ & 16 & $29 \%$ \\
\hline 8 & $\begin{array}{l}\text { Do you like the way the texts were } \\
\text { selected? }\end{array}$ & 49 & $88 \%$ & 0 & $0 \%$ & 7 & $12 \%$ \\
\hline
\end{tabular}




\section{Discussion}

Table 1 reveals that even when some of the students claim to love reading for pleasure, the percentage that like reading during extermination is higher than the percentage of those that like reading for pleasure. $46 \%$ like reading during exterminations while only $29 \%$ like reading for pleasure and $14 \%$ like reading textbooks and only $10 \%$ like reading newspapers. The reason is not a far-fetched one as there is frenzy usually when an examination is approaching. The students are more or less responding to these fears which motivate them to read to avoid failure. Also, with the advent of modern means of entertainment like the social media, television, computer games etc, most students have less time for reading especially when there are no threats of examinations attached to the reading. Children of nowadays find more joy in watching films and engaging friends on social media rather than reading.

The pre-study of students reading to write also shows that students of secondary schools in Ogba/Egbema/Ndoni Local Government rarely engage in reading to write exercise. $29 \%$ of the students said they engage in reading to write once a term and $21 \%$ use the method during composition exercise and $18 \%$ for once a week. Though some claim to read during leisure, pre-study reveal that only $18 \%$ of the population read during leisure. Most of the students (29\%) agree to the fact that they use the reading to write model only once a term which is very poor for effective writing. This goes to show that it is not common among students and teachers as a very good model for learning how to write. Most of the students in the previous classes were not introduced to the model of reading to write and as such it is not part of them; hence the high failure rate in writing tests and examinations in Nigerian schools which contributes highly to the poor performance of students in Senior Secondary Certificate examination as noted by Faniran (2011). Faniran (2011) states that:

Candidate' SSCE results in English Language have been embarrassingly poor. For instance, only two per cent (2\%) of the candidates who sat for the 2009 November/December SSCE of NECO had five credits including English Language and Mathematics (Nigerian Tribune, March 31, 2010, p. 17); and seventy-nine per cent (79\%) of the candidates who wrote the Examination in June/July 2010 failed to get credit passes in English Language, (The Punch October, 7, p. 14). These extremely poor result in English, the language of education and leaning and academic empowerment points to an important fact: that the Nigerian educational system is heading for total collapse (p.2).

If a deeper investigation is done on the aspects that contributed to these failure rates, it would not be surprising to discover that the writing aspect of the examination contributed immensely to the failure.

In table 2, which shows the result of the questionnaires given to the students after the researchers have introduced the mehtod of reading to write to the students and both the researchers and the students practically participated in the exercises shows that the highest percentage of the students confirmed that they enjoyed the session; where $89 \%$ enjoyed the session while $4 \%$ did not. Also, $64 \%$ were able to complete the selected text while $5 \%$ could not complete the selected text. $71 \%$ of the students from the table confirmed that this exercise will help them to improve in their writing skills. And $82 \%$ want their teachers to adopt this method in teaching writing while $91 \%$ believes that this exercise will help them to read more after the exercise. However, a good number of the students (73\%) felt it is a rewarding exercise that it will positively improve their language skills.

From the tables above, it is clear from the respondents that reading to write will improve students writing skills as well as their language/grammar, it makes students to be an active participant in the class since they are involve in the selection of the textbooks as well as the reading.

\section{Presentation of Results}

This chapter is concerned with the presentation of results from data analysis. The results are presented in tables according to the research questions and hypotheses that guided the study.

\section{Research Question 1:}

What are the Mean achievement scores of students taught using reading method of learning English Language and those taught using conventional writing method? 
Table 1. Mean and Standard deviation of pretest and posttest achievement scores of students engagement in reading to writing.

\begin{tabular}{lllllll}
\hline Variables & & Pre test & & Posttest & Mean gain \\
Teaching Method & $\mathrm{N}$ & $\boldsymbol{x}$ & $\mathrm{SD}$ & $\boldsymbol{x}$ & $\mathrm{SD}$ & \\
\hline Reading Method & 28 & 21.46 & 6.12 & 31.62 & 6.85 & 10.16 \\
Writing Method & 28 & 21.07 & 5.84 & 29.53 & 6.96 & 8.46 \\
Total & 56 & 21.25 & 5.92 & 30.50 & 6.82 & 9.25
\end{tabular}

Results on Table 1 show that the experimental group taught using reading to write technique had a pretest mean of 21.46 with a standard deviation of 6.12 and a posttest mean of 31.62 with a standard deviation of 6.85. The difference between the pretest and posttest mean for the experimental group was 10.16. The control group taught using convectional writing method had a pretest mean of 21.07 with a standard deviation of 5.84 and a posttest mean of 29.53 with a standard deviation of 6.96. The difference between the pretest and posttest mean for control group was 8.46. Results on table 1 also show that the total pretest mean score for both experimental and control group was 21.25 with a standard deviation of 5.92 and a posttest mean of 30.50 with a standard deviation of 6.82. The difference between the pretest and posttest mean for the total group was 9.25. However, for each of the groups, the posttest means were greater than the pretest means with the experimental group having the highest mean gain. This is an indication that reading method had some effects on students' achievement to conventional writing method.

\section{Research Question 2:}

What are the mean achievement scores of male and female students in reading to write as a strategy for improving learning of English language in Secondary School?

Table 2. Mean and Standard deviation of pretest and posttest scores of male and female students in reading to write as a strategy for improving learning?

\begin{tabular}{|c|c|c|c|c|c|c|}
\hline \multicolumn{2}{|l|}{ Variable } & \multicolumn{2}{|c|}{ Pretest Inst. } & \multicolumn{2}{|c|}{ Posttest Inst. } & \multirow[t]{2}{*}{ Mean gain } \\
\hline Gender & $\mathrm{N}$ & $x$ & SD & $\mathcal{X}$ & SD & \\
\hline Male & 26 & 47.39 & 7.76 & 62.48 & 9.74 & 15.09 \\
\hline Female & 30 & 47.04 & 8.55 & 63.99 & 9.55 & 16.95 \\
\hline Total & 56 & 47.22 & 8.12 & 63.19 & 9.65 & 15.97 \\
\hline
\end{tabular}

Results on Table 2 showed the pretest and posttest mean and standard deviations of male and female students taught using reading to write strategy. Result showed that the male students had a pretest means score of 47.39 with a standard deviation of 7.76 and a posttest mean score of 62.48 with a standard deviation of 9.74. The difference between the pretest and posttest mean score for the male students was 15.09. Result also showed that the female students taught using reading to write technique had a pretest mean of 47.04 with a standard deviation of 8.55 and a posttest mean of 63.99 with a standard deviation of 9.55. The difference between the pretest and posttest mean score for female students was 16.95. Results on table 2 also showed that the total pretest mean score for both male and female students was 47.22 with a standard deviation of 8.12 and a posttest mean score of 63.19 with a standard deviation of 9.65. The difference between the pretest and posttest mean score for both male and female students was 15.97. However, for both male and female students, the posttest mean scores were greater than the pretest mean scores with the female students having the higher mean gain. This result showed that gender may have some effects on students' achievement in English Language.

\section{Hypotheses 1}

$\mathbf{H}_{\mathbf{0 1}}$ : There is no significant difference in the mean achievement scores of students taught using reading method of learning English Language and those taught using conventional writing method?. 
Table 4. Analysis of Covariance (ANCOVA) of students' Achievement in reading to write as a strategy for improving learning of English Language.

\begin{tabular}{llllll}
\hline Source & $\begin{array}{l}\text { Type III Sum of } \\
\text { Squares }\end{array}$ & & Mean Square & F & Sig. \\
\hline Corrected Model & $728.520^{\mathrm{a}}$ & 4 & 182.130 & 4.864 & .002 \\
Intercept & 3833.390 & 1 & 3833.390 & 102.385 & .000 \\
Pretest Scores & 20.222 & 1 & 20.222 & .540 & .466 \\
Groups & 569.404 & 1 & 569.404 & 15.208 & .000 \\
Error & 61909.480 & 51 & 35.441 & & \\
Total & 54732.000 & 56 & & & \\
Corrected Total & 2638.000 & 55 & & & \\
\hline a. R Squared $=.276$ (Adjusted R Squared =.219) & & &
\end{tabular}

The result in Table 3 shows that with respect to the achievement mean scores of students taught using reading to write method of learning English Language composition and those taught with conventional writing method, an F-ratio of 15.208 was obtained with associated exact probability value of 0.00 . Since the associated probability value (0.00) was less than 0.05 set as bench mark, the null hypothesis $\left(\mathrm{H}_{01}\right)$ which stated that there is no significant difference in the mean achievement scores of students taught using r eading to write method of learning English Language composition and those taught with conventional writing method was rejected. Thus, inference drawn is that, there was a significant difference in the mean achievement scores of students taught using reading method of learning English Language and those taught with conventional writing method with the students taught using writing method of improve learning having a higher mean in the posttest. This result showed that writing method of teaching and learning resulted in an improvement of students' achievement in English Language. Although both reading method and writing strategies of teaching and learning resulted in an improvement of students' scores, writing technique had a higher mean gain.

\section{Summary of the Findings}

This section of the chapter is a summary of the findings of the study according to each of the tested hypotheses. From the data analysis and interpretation of the results, the following findings emerged;

There was a significant difference in the mean achievement scores of students taught using reading to write method of learning English Language composition and those taught with conventional writing method, with the students taught using writing technique having a higher mean in the posttest.

\section{Recommendations}

The study recommends the following:

- $\quad$ The method of Reading to write should be practically enshrine in the curriculum and teaching methodologies of present day English language teachers as the model is not currently reorganized in the curriculum.

- $\quad$ Seminars and symposiums should be organized by the Federal and State Ministries of Education to sensitize English language teachers in the secondary schools on the need to adopt the method and how to go about it.

- $\quad$ Current textbooks on the English language especially the ones targeted at teaching writing skills should adopt the Reading to Write method so that teachers and students would have resources to fall back on for assistance in the methodology.

- $\quad$ Students should be highly encouraged to read text especially literary materials to aid their writings.

- $\quad$ Lastly, the study recommends that the Reading to Write Method be introduced to the students at a very period in the educational pursuit preferably in their early basic education period.

\section{Conclusion}

This research emphasized that reading and writing often draw from the same pool of background knowledge. That is, both reading and writing transact ideas and styles. Reading gives you the general understanding of the texts while readers form a mental representation of thoughts written by someone else while writers formulate their own thoughts, organize them, and create a written record of them using the conventions of spelling and grammar. Therefore, reading and writing are both vital aspects of literacy that every individual desire. It is indisputable here that good readers are 
good writers therefore reading to write remain the best techniques for teaching writing. From the pre-test and post-test, it shows that students like reading most during examination even though some students clamed to read during leisure but the percentage cannot be compared to the percentage of those that like reading during exams and test.

\section{References}

Block,C.C. \& Presely, M. (2002). Comprehension research-based instruction. New York: Gulford.

Faniran, A.O. (2011). The English Language for empowerment in Nigeria. In English Language teaching today: proceedings of the annual ELTT conference, 5, 118-129.

Graham, S. Teaching writing. P. Hogan( ed), Cambridge Encyclopedia of Language science, (848-851).

Ikota, N.R. (2004). Reading to write: A strategy for improving the writing performance of pre-service student teachers of English language. Literacy and Reading in Nigeria, 10(1), 105-112.

Nweke, K.M.C. (1990). Awareness of readership promotion campaign in Nigeria: A survey of Ibadan Metropolis. Nigeria Library and Information Science Review, 8(2), 10-11.

Olson, C.B. (2003). The Reading/writing connection: Strategies for teaching and learning in the classroom. Bostom M.A: Allyn and Bacon.

Sagaeo, S. (1999). Reading habit promotion in ASEAN Libraries. $65^{\text {th }}$ IFLA Council and General Conference, August 20-28, Bangkok, Thailand. Available in www.ifa.org

Uche, A. (2007). Language teaching and learning. Onitsha: Africana-first Publishers Limited .

Unoh, S.O. (1980). Reading problems in secondary schools: Some observations and research findings. Journals of Language Arts and Communication, 1(1).

Yani, S. (2003). Reading habits of senior secondary school students in Zaria local government area. Zaria. Journal of Librarianship, 6(1\&2), 30.

Yusuf, F. (2007). Repositioning school libraries in Nigeria: the catalyst for promoting reading habits among primary and secondary school students. Retrieved on $14^{\text {th }}$ April 2016 from www.readingmatrix.com/article/adeyinka/article/pdf. 